\title{
The Distribution of Enset Pests and Pathogens and a Genomic Survey of Enset Xanthomonas Wilt
}

*Corresponding author: J. S. Borrell; E-mail: J.borrell@kew.org

${ }^{1}$ Southern Agricultural Research Institute, Hawassa, Southern Nations Nationalities and Peoples Regional State, Ethiopia.

2Department of Natural Capital and Plant Health, Royal Botanic Gardens, Kew, Richmond, Surrey, TW9 3AE, UK

${ }^{3}$ Department of Genetics and Genome Biology, University of Leicester, LR1 7RH, UK

${ }^{4}$ Department of Biology, Hawassa University, Hawassa, Ethiopia

${ }^{5}$ School of Life Sciences, University of Warwick, Coventry CV4 7AL, UK

${ }^{6}$ Bioversity International, Addis Ababa office, c/o ILRI, P.O. Box 5689, Addis Ababa, Ethiopia

\author{
†Joint first authors \\ Zerihun Yemataw ${ }^{1 \dagger}$, James S. Borrell ${ }^{2 \uparrow}$, Manosh Kumar Biswas ${ }^{3}$, Oliver White ${ }^{2}$, \\ Heslop Harrison ${ }^{3}$, Guy Blomme ${ }^{6}$, Paul Wilkin²
}




\section{Abstract}

Mapping the distribution of crop pests and pathogens is essential to safeguard food security and sustainable livelihoods. However, these data are unavailable for many neglected and underutilised crops, particularly in developing countries. In Ethiopia, the world's largest historic recipient of food aid, the indigenous banana relative enset (Ensete ventricosum) is threatened by multiple pests and pathogens whilst providing the staple starch source for 20 million people. Foremost among these is Xanthomonas Wilt of enset (EXW), caused by Xanthomonas vasicola pv. musacearum $(X v m)$, a globally important disease of bananas (Musa sp.) that likely originated in enset. Here we collate 1069 farm surveys to map the distribution and relative prevalence of enset pests and pathogens across the entire enset growing region. We find that EXW is the most frequently encountered pathogen, and that farmers consistently ranked EXW as the most significant constraint on enset agriculture. Our surveys also showed that corm rot, and the pests root mealybug, mole rat and porcupine are all virtually ubiquitous. Finally, we apply genotyping-by-sequencing to the detection of Xvm and demonstrate that it is present even in asymptomatic domesticated and wild enset samples, suggesting that management of plants displaying symptoms alone may not be sufficient to reduce disease transmission. Holistic understanding of pests and pathogen distributions in enset may have significant benefits for both food security in Ethiopia, and preventing proliferation in related crops such as banana across central and east Africa. 


\section{Introduction}

47 The increasing transmission of plant pests and pathogens has significant consequences

48 for the distribution, quality and yield of crops (Bebber et al. 2014; Savary et al. 2019).

49 Rural subsistence farmers appear particularly susceptible to these impacts, where

50 emergence or outbreaks of pests and pathogens exacerbates existing food insecurity

51 (Bruce 2010; Vurro et al. 2010) or hinders agricultural resilience (Heeb et al. 2019). Whilst

52 global surveillance systems exist for pest and pathogens of major crops (Forum et al.

53 2019), basic distribution, prevalence and incidence data is missing for many neglected

54 and underutilized plants which are likely to become increasingly important in future

55 diversified food systems (Borrell et al. 2019).

56 This paucity of monitoring data is a major challenge in Ethiopia where enset (Ensete

57 ventricosum (Welw.) Cheesman), an indigenous banana relative, provides food security

58 for 20 million people, but is threatened by multiple poorly documented pests and

59 pathogens (Jones 2000, 2018; Blomme et al. 2017; Borrell et al. 2019). Enset cultivation

60 is largely restricted to south and southwest Ethiopia (Figure 1A) where it is grown

61 principally as a subsistence crop and for regional markets, and often comprises a

62 significant proportion of total farm area (Borrell et al. 2020; Sahle et al. 2018). Enset is a

63 monocarpic perennial that can grow for up to a decade before reaching maturity and is

64 readily vegetatively propagated. Farmers maintain a cycle of plantings and transplantings

65 of various ages that can be harvested at any time prior to flowering and senescence.

66 Following harvest, the pseudostem and corm are pulped and fermented to provide a

67 storable starch source (Tamrat et al. 2020). This flexible system enables farmers to buffer 
seasonal food deficits, earning enset the moniker 'the tree against hunger' (Brandt et al. 1997).

Enset production is affected by multiple pests and pathogens of varying severity (Table 1, Figure 1). Important biotic constraints include Enset Xanthomonas Wilt (EXW, bacterial rots (Erwinia sp.) and root mealybugs (Blomme et al. 2017; Bogale et al. 2004; Addis, Azerefegne, Blomme, et al. 2008; Tewodros and Tesfaye 2014; Shank and Ertiro 1996). EXW is caused by Xanthomonas vasicola pv. musacearum (Xvm) (formerly X. campestris pv. musacearum). For clarity, in this manuscript we follow Studholme et al., 2019 and refer to the causal organism as $X$. vasicola pv. musacearum, except when discussing NCBI the reference genome which is still accessioned as $X$. campestris pv. musacearum. Mammal pests that directly damage the plants include porcupine, mole rats, wild pigs and monkeys (Bobosha 2003), and these are also suspected vectors of disease transmission, especially EXW, hence they are included in this study (Hunduma et al. 2015; Pers. Obs. J.S. Borrell).

Among these pests and pathogens, EXW is frequently cited as the most significant concern for farmers, generating a large number of studies that seek to identify tolerant or resistant enset landraces (Hunduma et al. 2015; G Welde-Michael et al. 2008; Yemataw et al. 2016; Muzemil et al. 2020; Haile et al. 2020) Xvm infects the vascular system of enset, damaging the harvestable tissue, causing permanent wilting and eventually death (Yemataw et al. 2017). It is known to be transmitted by contaminated tools and infected planting material, and potentially biotic vectors, such as wild and domesticated animals that browse part of the corm or pseudostem (Yemataw et al. 2017; Addis et al. 2010). In a previous study across 320 farms in eight districts, $40 \%$ of respondents reported EXW in 
91 their field (McKnight-CCRP 2013), though this varied by region from 3.3\% (Kembata

92 Tembaro) to $95.7 \%$ (Gedeo), and the authors suggest that the true infection rate (farm

93 prevalence) could be as high as $80 \%$. Some authors claim that EXW has forced farmers

94 to abandon enset production (Spring 1996; Tadesse et al. 2003). EXW is also speculated

95 to be a possible driver for a reported major historic decline in enset agriculture in the North

96 of Ethiopia ( 200 years b.p.), though there is a lack of evidence to support or refute this

97 (Brandt et al. 1997).

98 The causative agent of EXW was first described by Yirgou and Bradbury (1968) in

99 Ethiopia. However symptoms consistent with EXW were reported as early as the 1930s

100 (Castellani 1939; Studholme et al. 2019; Blomme et al. 2017), though it is not clear

101 whether this represents emergence of the disease, or simply the first scientific

102 documentation. During the $1960-80$ s the pathogen spread rapidly in enset and banana

103 (Musa sp.) in Ethiopia (Yemataw et al. 2017) and is now a threat to smallholder banana

104 cultivation throughout central and eastern Africa (Carter et al. 2010), impacting food

105 security and rural livelihoods (Blomme et al. 2013, 2017). As a result, improved

106 understanding of Xvm's spatial distribution, intensity and impact on farmers is key to

107 continued food security, as well as supporting translational research in enset and 108 bananas (Merga et al. 2019). Two previous studies surveyed banana Xanthomonas wilt 109 (BXW) in the East African highlands (not including Ethiopia) (Bouwmeester et al. 2016) 110 and the risk of BXW more widely across Africa (Ocimati et al. 2019), but not at a resolution 111 that is informative for disease mapping or management in Ethiopia, the putative origin of 112 the disease. 
113 Compared with $X v m / E X W$, the distribution, prevalence and impact of other enset pests and 114 pathogens has received much less attention. Enset corm rot is thought to be caused by 115 Erwinia (or Dickeya) species (Blomme et al. 2017), but is poorly characterised. A survey by Yirgu (2016) in the Gamo Highlands found that a quarter of respondents considered

117 corm rot to be the most severe disease of enset. Enset root mealybug (Cataenococcus 118 ensete Williams and Matile-Ferrero) is known to be a locally important pest, with evidence 119 that infestation retards growth, reduces pseudostem circumference and associated yields 120 (Addis et al. 2008; Azerefegne et al. 2009). Addis (2005) reported that $30 \%$ of sampled 121 farms were infected. Limited surveys of nematodes and weevils were undertaken by 122 Bogale et al. (2004), which found relatively low nematode densities and did not find weevils. The banana weevil Cosmopolites sordidus does not thrive well above 1,600 m 124 asl (Lescot 1988), and most enset cultivation zones are located at higher altitudes. Leaf 125 hopper was found to be widespread in Yem special district, and associated with EXW prevalence (Zerfu et al. 2018). There remains the possibility of additional undescribed

127 pathogens, in both wild and domesticated populations. date of the pests and pathogens affecting enset agriculture in Ethiopia, with a particular focus on detecting EXW. To achieve this, we first use region-wide farmer interviews and farm surveys to evaluate the relative abundance of pests and pathogens on enset farms, 132 and farmer perceptions of the major constraints on enset agriculture. Second, we collate a suite of high-resolution environmental, topographic and socioeconomic variables for the 134 study area and apply these to characterise the spatial distribution and prevalence of major enset pests and pathogens across the enset growing region. Finally, we apply a 
genotyping-by-sequence approach to survey the leaf-associated microbiota of EXWsymptomatic and non-symptomatic enset samples, to assess detection efficacy of diseased versus incubating or asymptomatic $X v m$ and improve our understanding of EXW transmission. We discuss these data in the context of ongoing monitoring of pests and pathogens in a neglected food security crop, to support diagnosis, monitoring and management.

\section{Materials and Methods}

\section{Enset pests and pathogen surveys}

This study comprises observations from two region-wide surveys, conducted independently by i) the Southern Agricultural Research Institute between 2014-17 $(n=585)$, hereafter SARI and ii) a team from Royal Botanic Gardens Kew, Wolkite and Hawassa Universities 2017-20 $(n=484)$, hereafter KWH. Both surveys were independently conceived, designed and carried out over a broadly similar geographic area (Figure 2A), using a similar methodology and as a result we are confident that comparing and combining these data make our conclusions more robust.

Both surveys were conducted by experienced teams together with local agricultural extension agents, and randomly selected individual farms over stratified sampling regions. Data was collected via individual interviews and direct on-farm participatory observations, and all diseases scored as presence or absence. Both surveys recorded the presence of five major pests and pathogens: EXW, root mealybug, corm rot, mole rat and porcupine, as well as estimating the number of enset plants with symptoms of EXW.

The SARI survey additionally recorded leaf hoppers and wild pig damage, and asked 
158 farmers to identify the most important constraint on enset production. The KWH survey 159 additionally recorded nematodes, leafspot, monkey damage and weevils. Survey 160 methodologies were broadly consistent; applying semi-structured interview, disease 161 identification sheets and visual inspection of infected or damaged plants. The order in 162 which diseases were presented, and the diagnostic photographs shown were varied to 163 mitigate reporting bias. We also sought to document any symptoms of similar magnitude 164 that were not attributed to known pests and diseases.

165 We calculated the relative prevalence of pests and pathogens to compare consistency across surveys. Where a pest or pathogen was only recorded in one survey, we record

167 prevalence relative to the number of farms in that survey. Due to road accessibility and logistics, surveys were conducted unevenly through the year. Therefore, these data are not sufficiently robust for assessing seasonal trends, though we provide a summary of seasonality in Supplementary Materials (Figure S1). Finally, we grouped farms based on

171 the top five farmer perceived constraints on enset agriculture and compared these with 172 pests and pathogens prevalence.

\section{Spatial modelling of pest and pathogen prevalence}

174 We collated 41 high-resolution environmental, topographic and socioeconomic variables.

175 Environmental variables were sourced from WorldClim (Fick and Hijmans 2017),

176 ENVIREM (Title and Bemmels 2018) and CliMond (Kriticos et al. 2012), together with a

$17790 \mathrm{~m}$ SRTM DEM sourced from Jarvis et al. (2008). Slope, aspect, topographic position

178 index and terrain roughness were calculated from elevation using the 'terrain' function in 179 the R package Raster (Hijmans 2017). Socioeconomic variables were derived from 180 OpenStreetMap (OpenStreetMap contributors 2015) and Gridded Population of the World 
181 v4 (Center for International Earth Science Information Network 2017). All variables were 182 resampled to $250 \mathrm{~m}$ resolution, for consistency with the high-resolution topographic variables. A full list of variables is provided in Supplementary Materials, Table S1. Despite 184 the resilience of our chosen analysis approach to highly correlated variables, to aid subsequent interpretation we removed 26 variables with very high collinearity using the 186 function vifcor in 'usdm' (th=0.8) (Naimi 2017; Lever et al. 2017). All analyses were 187 conducted in R software ( $\mathrm{R}$ Core team 2019).

188 To build robust models, we tested a range of cluster aggregation values to group farms by distance and sample size (see validation section), selecting a maximum aggregation 190 distance of $4000 \mathrm{~m}$ and $\geq 3$ surveyed farms (Supplementary Materials, Figure S2). We 191 chose a relatively fine scale aggregation due to the high environmental heterogeneity of 192 southwest Ethiopia. Prevalence was calculated as the proportion of farms affected within a cluster. Observation clusters with $<3$ surveyed farms were excluded from model 194 building. Environmental variables were then extracted for each surveyed farm, and 195 averaged by cluster.

196 To characterise the climatic niche of each enset pest and pathogen we used an approach 197 similar to that of Pironon et al. (2019). First, principal component analysis (PCA) was 198 performed on 100,000 systematically sampled points representing background climatic 199 space of the study area. In these analyses, the first two principal components summarise 200 the variation of the 15 retained variables. Second, we computed quantiles of pest and 201 pathogen prevalence from our survey data corresponding to the $10^{\text {th }}, 50^{\text {th }}$ and $90^{\text {th }}$ percentile. To characterise the niche occupied by a given pest or pathogen we plotted an alpha hull for each degree of pest and pathogen severity using the package 'alphahull' 
204 with an alpha value of 1.05 (Pateiro-lopez 2019). This approach visualises the most 205 severely affected farm clusters nested within the broader climatic space of surveyed 206 farms. Climatic space polygons were then replotted in geographical space using the $R$ 207 packages 'raster' and 'rgeos' (Hijmans 2017; Bivand et al. 2018).

208 To provide an indication of the strength of association between environmental variables and our predicted pest and pathogen niches, we randomly sampled each variable across our four overlapping prevalence polygons $(0,0.1,0.5$ and 0.9$)$ and estimated the Kendall rank correlation coefficient. We note that we did not estimate the significance of each

212 association, as this would be strongly influenced by the number of random samples.

213 Finally, we used the nicheOverlap function in the R package Dismo (Hijmans et al. 2017)

214 to estimate niche overlap between modelled pest and pathogen distributions for 0.1 and 2150.9 prevalence quantiles.

Model validation

217 We used three approaches to validate our spatial analysis. First, we performed a 218 sensitivity analysis by varying the aggregation distance and cluster threshold size of farm 219 surveys, then assessing the change in predicted area as a response. Second, we 220 modelled data from each survey separately and evaluated performance by comparing 221 predicted area. Finally, for EXW we use a generalized linear model to test the hypothesis 222 that aggregated survey points with greater disease prevalence also display greater 223 disease severity in the number of infected plants. 


\section{Diseased tissue sample collection and genotyping}

225 We collected leaf tissue samples from 10 enset individuals (multiple landraces),

226 displaying EXW symptoms. This was complemented by 233 domesticated and 14 wild

227 enset samples that did not display visible symptoms and were otherwise considered

228 healthy. Samples were widely distributed across the study area, with a maximum of three

229 from a single farm. Samples were principally collected for diversity analysis meaning they

230 encompass a broad range of putatively genetically distinct landraces. Leaf tissue was

231 silica dried, extracted using a standard CTAB protocol (Doyle \& Doyle 1987), normalised

232 and submitted to Data2Bio (IA, USA) for library preparation and tunable genotyping-by-

233 sequencing (tGBS) following the protocol of Ott et al. (2017). DNA samples were digested

234 with the restriction enzymes $\mathrm{Nspl}$ and $\mathrm{BfcCl} / \mathrm{Sau} 3 \mathrm{Al}$ before being sequenced using an

235 Ion Proton platform.

\section{Identification of candidate bacterial sequences}

237 We screened all samples for putative bacterial sequences by implementing a local blast search (Camacho et al. 2009) against a custom database of bacterial genome sequences created using NCBI Reference Sequences (RefSeq; O'Leary et al. 2016). Specifically, we

240 downloaded all complete bacterial genomes classified as "reference" or "representative"

241 resulting in a dataset comprised of 3,000 assemblies (date accessed $12^{\text {th }}$ June 2020;

242 Supplementary Table 2). In addition, we included genome sequences for Xanthomonas

243 campestris pv. musacearum (GenBank accession: GCA_000277875.1) and

244 Xanthomonas vasicola pv. vasculorum (GCA_003015715.1). Xanthomonas campestris

245 pv. musacearum was used as it is the causal agent of bacterial wilt in enset and banana

246 which has recently been reclassified as $X$. vasicola pv. musacearum (Aritua et al. 2008). 
247

248

249

250

251

252

253

254

255

256

257

258

259

260

261

262

263

264

265

266

267

268

Xanthomonas vasicola pv. vasculorum was included as it is a close relative of $\mathrm{Xvm}$ yet is non-pathogenic in banana (Wasukira et al. 2012).

Prior to the blast search, raw tGBS sequencing reads were quality filtered using Trimmomatic (Bolger et al. 2014). Duplicate sequences were filtered from our samples using CD-HIT (Fu et al. 2012). A blastn search of tGBS reads was performed against the custom bacterial genome refseq dataset with 10 maximum target sequences, one maximum high-scoring segment pair (HSP) and an expectation value $(E)$ of $1 \times 10^{-25}$. The taxonomy of a query sequence was defined using a "best sum bitscore" approach, where the bitscores for each subject taxonomy identified are summed and the taxonomy with the greatest score is selected. Where more than one taxonomy has the greatest sum bitscore no taxonomy is defined. This avoids ambiguous assignment with multiple closely related taxa in the blast database. Our approach was adapted from the methodology of blobtools2 (Challis et al. 2020) which was not appropriate for our analyses as it does not distinguish subspecific taxonomic ranks (i.e. pathovars).

For an overview of the bacteria present in and/or on leaf tissue, we first counted sequences assigned to each genus or species in our blast dataset. Taxa were scored as present in an individual if we identified $>5$ matching reads for that sample. To provide a sequence-depth independent estimate, we then calculated the base pair coverage of the $X$. vasicola pv. musacearum genome that was identified in our blast search. To do this, overlapping blast hits for $X$. vasicola pv. musacearum in each sample were merged using bedr in R (R Core team 2019) and total base pair coverage was calculated. We plotted these data in putative groupings comprising diseased, non-diseased and wild samples, and applied Analysis of Variance (ANOVA) and Tukey HSD post-hoc tests to assess 
270 differences between groups. Custom scripts used for the blast search, taxonomic

271 identification and coverage estimation are available form https://github.com/o-william-

272 white/Enset tGBS.

273 Results

\section{Farm and farmer surveys}

275 A total of 1069 farms were assessed across two survey campaigns (Figure 2A). Overall,

276 EXW was the most frequently recorded pest or pathogen, occurring in $41.2 \%$ of farms 277 with porcupine (40.2\%) and corm rot (37.6\%) also similarly abundant (Figure 2B). In a

278 comparison between surveys, corm rot, followed by porcupine and EXW was most

279 frequently encountered by SARI, whereas EXW, followed by porcupine and root 280 mealybug was most frequently encountered by HWK. Whilst the study area was largely 281 consistent, the distribution of survey effort across months differed between surveys, with 282 the majority of SARI survey effort in November-December and HWK in October and 283 January-April (Supplementary Materials, Figure S1). Of 577 farmer responses, 507 (88\%) 284 reported pests and pathogens as the predominant constraint on enset agriculture (Table 285 2). Of the remainder, 34 respondents reported no major constraint and others cited eight 286 additional abiotic constraints at low frequency, including drought, land shortage, frost and 287 labour shortage. Farmer perception of the predominant constraint on enset agriculture 288 was highly consistent with the frequency at which pest and pathogens were recorded on 289 farms (Table 2).

290 Spatial modelling of pests and pathogens 
291 We computed the niche space for the five major pest and pathogen species with sufficient

292 data and projected these into geographical space (Figure 3). Estimation of Kendall rank

293 correlation coefficients between environmental variables and modelled pest and

294 pathogen prevalence quantiles identified different suites of variables for each species

295 (Table 3). EXW was positively associated continentality and negatively associated with

296 the maximum temperature of the coldest month and potential evapotranspiration (PET)

297 of the coldest quarter. Corm rot was negatively associated with multiple PET variables

298 and root mealybug was negatively associated with isothermality and cold quarter

299 precipitation. Pairwise niche overlap at the 0.9 prevalence quantile was highest for EXW

300 - porcupine and EXW - corm rot respectively (Table 4).

301 Validation

302 We plotted the predicted area for each of the five species (at 0.5 and 0.9 disease prevalence quantiles) across a range of cluster aggregation distances and cluster minimum sizes (Supplementary Materials, Figure S3). These show that predicted areas

305 for most species stabilize at $4000 \mathrm{~m}$ and clusters of 3 or more farms. At very high cluster values (>7), the predicted area declined, which we attribute to declining sample sizes

307 reducing our ability to predict across climatic space. Comparison of models derived from each survey individually showed a significant correlation in predicted area $\left(F_{1,13}=115\right.$, $R^{2}=0.89, p=<0.001$ ) (Supplementary Materials, Figure S4). Finally, we report a highly significant relationship between the proportion of farm clusters reporting EXW and the mean count of EXW infected enset $\left(F_{118}=1.78, p=0.008\right)$ (Figure S5). 
313 In a large sample of visibly non-diseased domesticated plants, bacteria of the genera

314 Acinetobacter, Cyanobacterium, and Pseudomonas were most abundant, whilst Nostoc

315 and Oscillatoria were less abundant but recorded in a high proportion of individuals

316 (Figure 4A). A similar, but more diverse and abundant assemblage was recorded in visibly

317 non-diseased wild plants, including the genera Methylobacterium and Sphingomonas

318 (Figure 4C). We note that whilst Methylobacterium has been reported as a frequent laboratory contaminant (Salter et al. 2014), here it is largely localised to wild samples extracted using multiple kits and sequenced on different plates, suggesting this is a valid

321 finding. By contrast, the diseased domesticated sample group was characterised by a

322 very high mean number of reads of Xanthomonas, present in all samples (Figure 4B). It

323 is noteworthy, however, that reads corresponding to Xanthomonas were also identified in

$324>57 \%$ of non-diseased domesticated samples and $>86 \%$ of wild samples. Of the 19

325 Xanthomonas reference genomes in our blast database, X. campestris pv. musacearum

326 (i.e. $X v m$ ) was the most frequently identified species (Figure 4D). Finally, retaining only

327 reads aligning to $X v m$, we calculated the coverage of the blast hits against the genome

328 for each sample and plotted these by group (Figure 4E). The recovered sequence length

329 significantly differed across groups $\left(F_{(2,254)}=46.2, P=<0.001\right)$, despite no significant

330 difference in raw read counts between the three groups $\left(F_{(2,254)}=1.08, p=0.34\right)$. $A$ Tukey

331 post-hoc test indicated significant $X v m$ genome coverage differences between the

332 domesticated and diseased groups $(p<0.001)$ and wild and diseased groups $(p<0.001)$.

333 However, there was no significant difference between wild and domesticated $(p=0.99)$.

334 Of 233 asymptomatic domesticated plant samples, 36 (15\%) reported a count of Xvm 335 aligning reads equal to or higher than an EXW symptomatic sample. A further $150(64 \%)$ 
plants reported a non-zero number of $X v m$ aligning reads. We plot the distribution of our diseased reference plants and the 36 asymptomatic plants with an equal, or higher number of $X v m$ reads in Figure 5.

\section{Discussion}

The distribution and intensity of pests and pathogens in neglected and underutilised crop species is often poorly known, limiting the effectiveness of mitigation strategies (Bebber et al. 2019). In this study we collate 1069 farm surveys to provide the most detailed analysis to date of the distribution and prevalence of pest and pathogens on enset farms in Ethiopia, together with the perceptions of enset farmers, to develop a baseline from which to assess future trends.

\section{Farmer surveys}

The most frequently recorded pest or pathogen was EXW, occurring on $42 \%$ of farms (Figure 2). This is consistent with multiple previous reports emphasising the importance of EXW as a constraint to enset agriculture (Shimelash et al. 2008; Merga et al. 2019; Wolde et al. 2016). However, we found that other much less studied pests and pathogens are also virtually ubiquitous across the enset growing region. Corm rot and root mealybug were reported on $37.6 \%$ and $32.6 \%$ of farms respectively. Whilst we know that both EXW and corm rot can result in loss of whole plants, the associated reduction in yield due to mealybug infestation is not known.

Despite large sample sizes, we observed differences in disease prevalence between the two surveys. These may be attributed to a number of causes, particularly survey timing and variation of disease prevalence across overlapping survey areas. Though our 
sampling strategy was not designed to ascertain seasonal trends (and so must be used with caution for this purpose), we note that SARI performed a large number of surveys in November and December, a period shortly after the long rainy season in which we see an increase in the number of corm rot observations (Supplementary materials, Figure S1). This may partly account for the disparity in corm rot observations. Observations for EXW, root mealybug and porcupine were largely consistent between surveys. These comparisons emphasise the value of multiple independent surveys, particularly where pathogens are poorly known and may be cryptic.

Our findings are consistent with farmer perceptions, with over $40 \%$ reporting EXW to be the primary constraint on enset agriculture (Table 2 ). However, only $71 \%$ of farmers that report EXW as the primary constraint were found to have EXW on their farms. This is in contrast with farmers who reported other pests and pathogens as their primary constraint, where our surveys found the reported pest or pathogen present on the farm $>97 \%$ of the time. Therefore, EXW is considered a greater constraint by farmers than would be assumed from its frequency alone. This could be due to the potentially devastating impact of EXW, and the risk of greater livelihood and food security consequences than from other pests and pathogens (Azerefegne et al. 2009; Savary et al. 2012; Borrell et al. 2019). For banana farmers in East and Central Africa, Banana Xanthomonas Wilt (BXW) is also ranked above other pests and pathogens (Tushemereirwe et al. 2006; Blomme et al. 2017).

The prevalence of EXW on Ethiopian enset farms is similar or slightly less severe than published reports of BXW elsewhere in east Africa. In a large survey in Uganda, Nakato et al. (2016) recorded BXW in 69-75\% of farms, and in Rwanda, Uwamahoro et al. (2019) 
381 found prevalence varied from $26-82 \%$ of farms. If EXW is indeed less prevalent, it is possible that a) enset is less susceptible to $X v m, b)$ its presence for nearly a century has helped farmers select for a larger proportion of tolerant landraces, c) the lack of insectvectored transmission with enset reduces observed prevalence and especially incidence and/or d) another factor such as environment or cultural practice reduces disease prevalence. Relatively few surveys in Ethiopia have focused on BXW, to provide a comparison, though a study by Shimelash et al. (2008) reported that the number of infected plants varied from $\sim 2-40 \%$ across a series of sampling sites stratified by and altitudinally isolated from the principal area of enset cultivation, which may have served to limit the incidence of $X v m$ in lowland banana production zones.

\section{Distribution of pest and pathogens}

We modelled the distribution of five major pest and pathogens and found all to be virtually ubiquitous across the survey area (Figure 3). This helps explain why previous studies have found it challenging to identify hotspots in pathogens such as EXW (Wolde et al. 2016; Brandt et al. 1997). Our observations were largely consistent across a range of parameters and both independent surveys (Figures S3, S4). Despite the broad distribution of most pests and pathogens, we did observe variation in relative disease prevalence consistent with our limited knowledge on pest and pathogen ecology. For example, the most severely affected regions for Root mealybug appear to be low lying

401 areas along the Great Rift Valley, consistent with reports that mealybugs are most 402 common in moist, humid localities and that they can be dispersed via flooding events 403 (Azerefegne et al. 2009). Similarly, we show that corm rot is negatively correlated with 
404 drier localities (higher potential evapotranspiration) which are likely to be less amenable to bacterial multiplication. EXW was more weakly associated with multiple environmental variables, the most important being maximum temperatures and potential evapotranspiration in the coldest quarter. Interestingly, EXW was most strongly positively associated with Continentality (average temperature of the warmest month, minus coldest month). Higher Continentality values are typical of areas where domesticated has expanded beyond the range of wild enset.

411 Additional unmeasured variables are also likely to be important in refining these models 412 and our understanding of enset disease ecology. For example, the wide diversity of 413 cultural practices may regionally facilitate or hinder control of pests or transmission of 414 pathogens. Whilst we did not find that 'distance to roads' was a strong predictor as might 415 have been expected for pathogens such as EXW and root mealybug that can be 416 transmitted through planting materials, other socioeconomic variables such as farm

417 density or the proportion of enset in the local crop mix, may be important. Whilst some 418 data on the prevalence of enset agriculture is available (Borrell et al. 2020), these data 419 are not at a sufficiently high resolution to be analytically tractable. Pests and pathogens 420 may also vary in their ecology and virulence (Goss and Bergelson 2006). For example, 421 researchers screening enset landraces for $X v m$ tolerance have reported varying virulence

422 across Xvm isolates (Muzemil et al. 2020; Merga et al. 2019; G Welde-Michael et al. 423 2008). Finally, while our data captures pest and pathogen farm-level prevalence, it does 424 not quantify disease incidence or severity i.e. the impact on yield or livelihoods. Future 425 surveys focused on quantifying yield reduction would complement this work. 
427 In this study, we are confident that we have detected $X$. vasicola pv. musacearum in 428 'diseased' samples as they display the known disease phenotype and a large number of 429 reads blast align to the Xvm genome sequence (Figure 4). Surprisingly, we also detected 430 a significant number of $X v m$ reads in asymptomatic domesticated and wild enset plant 431 samples. There are three possible explanations for this observation. First, a subset of 432 landraces may display some tolerance or resistance meaning that the pathogen can be 433 present without causing symptoms. Second, we may be detecting a non-pathogenic or 434 closely related Xanthomonas pathovar in our asymptomatic samples (Alemayehu et al. 435 2016). This is supported by the fact that variation in the pathogenicity of different strains has been reported previously (G Welde-Michael et al. 2008; Merga et al. 2019; Muzemil 437 et al. 2020; Haile et al. 2020). Finally, it is possible that we are detecting Xvm during the 438 incubation period. The incubation period in enset appears to be longer than in Musa, 439 though this depends on the infected landrace, entry point of the pathogen, inoculum level and age of the plants (Ocimati et al. 2013; G. Welde-Michael et al. 2008; G Welde-Michael

441 et al. 2008). In this case we would conclude that Xvm is present, and may eventually 442 cause symptoms. We note that long term latent infections have been reported in East 443 african bananas (Ocimati et al. 2013). It is also noteworthy that we detect $X v m$ in wild 444 enset, which is consistent with reports by Alemayehu et al. (2016) of wild enset 445 susceptibility. However unlike Alemayehu et al., throughout our extensive fieldwork we 446 have not observed a wild enset plant displaying EXW symptoms and it is not clear how $447 \quad X v m$ could cross generations in a wild unmanaged population.

448 We consider it plausible that all three explanations may be responsible to varying 
450 individuals, this probably does not explain detection of $X v m$ in nearly half of asymptomatic 451 domesticated plants and nearly all wild plants. Therefore, tolerance of low levels of Xvm

452 and the existence of latent infections, coupled with a possible wider diversity and varying 453 pathogenicity of $X v m$ in enset agricultural systems, suggests that the overall distribution 454 of this pathogen may have been underestimated.

\section{Current research gaps}

456 Building on the first region wide pest and pathogen distribution maps, we attempt to 457 identify major outstanding research gaps. Firstly, whilst a growing number of studies are 458 surveying putatively EXW tolerant or resistant enset landraces it remains to be understood why EXW appears to predominantly affect 4-5 year old plants (Wolde et al. 2016) (or whether that is simply observation bias as these are likely to be the most 461 common group demographically). Secondly, abiotic stress prior to infection can 462 predispose plants to pathogen susceptibility (Bostock et al. 2014). It is possible that 463 susceptibility to EXW is exacerbated by abiotic stress, such as drought or cold shock, 464 though the underlying processes may be much more complex (Neil et al. 2017). It would 465 be worthwhile to identify a stratified sample of farms for continued repeat EXW surveys 466 to understand seasonality patterns in severity. Similarly, transmission may be higher

467 under certain environmental conditions. Shimwela et al. (2016) reported higher BXW 468 incidence during the rainy season, attributed to higher water levels in plant tissue 469 favouring bacteria development. This suggests that transmission can also be higher in 470 wet conditions as inoculum levels may be elevated (Blomme et al. 2017), and tool use 471 increases for management reasons. Finally, we have not addressed potential 472 interactions, for example, whether root mealybug infestation makes enset more 
473 susceptible to EXW, or facilitates entry of the pathogen into the roots or corm. However

474 we note the strong niche overlap between porcupine (as a putative vector) and both EXW

475 and corm rot (Table 4).

476 Conclusions

477 In conclusion, farmers clearly consider EXW to be the predominant constraint on enset 478 agriculture. Their concern may be justified based on evidence presented here that $X v m$ 479 is more widespread and prevalent than previously recognised, partly explaining the 480 propensity of EXW to appear unexpectedly. In a regional context, Xvm it can be

481 considered one of the most important and widespread disease of Musa in East and 482 Central Africa with significant economic and food security impacts. Whilst EXW has 483 proven to be a substantial challenge for effective disease management in small scale 484 farming settings, comparatively less research has been undertaken on corm rot and root 485 mealybug, which our data demonstrates are similarly widespread and prevalent. Whilst 486 they may not have the potential severity of EXW, they may cumulatively have a significant 487 impact on overall yields and food security. Despite the significant challenges that 488 pathogens such as $\mathrm{Xvm}$ pose, enset agriculture is rich in indigenous knowledge, 489 genetically diverse landraces and a wide range of agronomic practices; significantly more 490 so than in the introduced (in Ethiopia) genetically depauperate and agronomically uniform 491 Musa crop, which predominantly focusses on the Cavendish dessert banana types. This 492 suggests that further research in enset may have translational benefits for related species 493 in Ethiopia and beyond. 


\section{Acknowledgements}

495 We thank the Southern Agricultural Research Institute for providing logistical support, and 496 numerous agricultural extension agents for facilitating fieldwork.

$497 \quad$ Funding

498 The Global Challenges Research Fund, Foundation Awards for Global Agricultural and 499 Food Systems Research, entitled, 'Modelling and genomics resources to enhance 500 exploitation of the sustainable and diverse Ethiopian starch crop enset and support 501 livelihoods' [Grant No. BB/P02307X/1]; The European Community Horizon 2020 grant 502 Project ID 727624, “ Microbial uptake for sustainable management of major banana 503 pests and diseases (MUSA)" and The McKnight foundation.

\section{Author Contributions}

505 ZY, JB, WM and SM performed field surveys and collated data. JB designed and 506 performed spatial analysis with contributions from IO. MB and JD sequenced enset

507 tissue samples and OW processed and analysed sequence data. JB wrote the first draft 508 of the manuscript and produced the figures. All authors contributed to and approved the 509 final version of the manuscript. 


\section{Literature Cited}

Addis, T. 2010. Biology, Geographical Distribution, Prevention and Control of the Enset Root Mealybug, Cataenococcus ensete (Homoptera: Pseudococcidae) in Ethiopia. Tree For. Sci. Biotechnol. 8:251-260.

Addis, T., Azerefegne, F., and Blomme, G. 2008. Density and distribution on enset root mealybugs on enset. African Crop Sci. J. 16:67-74.

Addis, T., Azerefegne, F., Blomme, G., and K. Kanaujia. 2008. Biology of the Enset Root Mealybug Cataenococcus ensete and its Geographical Distribution in Southern Ethiopia. J. Appl. Biosci. 8:251-260.

Addis, T., Turyagyenda, L. F., Alemu, T., Karamura, E., and Blomme, G. 2010. Garden tool transmission of xanthomonas campestris pv. musacearum on banana (Musa spp.) and enset in Ethiopia. Acta Hortic. 879:367-372.

Alemayehu, C., Tadesse, K., and Guy, B. 2016. Natural occurrence and pathogenicity of Xanthomonas bacteria on selected plants. African J. Biotechnol. 15:2146-2155 Available at: http://academicjournals.org/journal/AJB/article-abstract/B6B571E60675.

Aritua, V., Parkinson, N., Thwaites, R., Heeney, J. V, Jones, D. R., Tushemereirwe, W., et al. 2008. Characterization of the Xanthomonas sp . causing wilt of enset and banana and its proposed reclassification as a strain of $X$. vasicola. :170-177.

Azerefegne, F., Addis, T., Alemu, T., Lemawork, S., Tadesse, E., Gemu, M., et al. 2009. An IPM guide for Enset root mealybug (Cataenococcus ensete) in Enset production.

Bebber, D. P., Field, E., Gui, H., Mortimer, P., Holmes, T., and Gurr, S. J. 2019. Many unreported crop pests and pathogens are probably already present. Glob. Chang. Biol. 25:2703-2713.

Bebber, D. P., Holmes, T., and Gurr, S. J. 2014. The global spread of crop pests and pathogens. Glob. Ecol. Biogeogr. 23:1398-1407.

Bivand, R., Stuetz, R., Ove, K., Giraudoux, P., Davis, M., and Santilli, S. 2018. Package ' rgeos $\therefore$ Available at: https://cran.r-project.org/web/packages/rgeos/rgeos.pdf.

Blomme, G., Dita, M., Jacobsen, K. S., Pérez Vicente, L., Molina, A., Ocimati, W., et al. 2017. Bacterial Diseases of Bananas and Enset: Current State of Knowledge and Integrated Approaches Toward Sustainable Management. Front. Plant Sci. 8:1-25 Available at: http://journal.frontiersin.org/article/10.3389/fpls.2017.01290/full.

Blomme, G., Ploetz, R., Jones, D., De Langhe, E., Price, N., Gold, C., et al. 2013. A historical overview of the appearance and spread of Musa pests and pathogens on the African continent: Highlighting the importance of clean Musa planting materials and quarantine measures. Ann. Appl. Biol. 162:4-26.

Bobosha, K. 2003. Characterization of Xanthomonas campestris pv musacearum isolates: causal agent of enset bacterial wilt disease.

Bogale, M., Mekete, T., and Protection, P. 2004. Survey of Plant Parasitic Nematodes and Banana Weevil. Nematol. Mediterr. 32:223-227 Available at: http://www.inaav.ba.cnr.it/vol32-2, 2004/vol32-2o.pdf. 
Bolger, A. M., Lohse, M., and Usadel, B. 2014. Trimmomatic: A flexible trimmer for Illumina sequence data. Bioinformatics. 30:2114-2120.

Borrell, J. S., Biswas, M. K., Goodwin, M., Blomme, G., Schwarzacher, T., Heslop-Harrison, P. J. S., et al. 2019. Enset in Ethiopia: a poorly characterised but resilient starch staple. Ann. Bot. $123(5): 747-766$.

Borrell, J. S., Dodsworth, S., Forest, F., Perez-Escobar, O. A., Lee, M. A., Mattana, E., et al. 2019. The climatic challenge: Which plants will people use in the next century? Environ. Exp. Bot. 170.

Borrell, J. S., Goodwin, M., Blomme, G., Jacobsen, K., Wendawek, A. M., Gashu, D., et al. 2020. Enset based agri-systems in Ethiopia: A systematic review of production trends, agronomy, processing and the wider food security applications of a neglected banana relative. Plants, People, Planet. 00:1-17.

Bostock, R. M., Pye, M. F., and Roubtsova, T. V. 2014. Predisposition in Plant Disease: Exploiting the Nexus in Abiotic and Biotic Stress Perception and Response. Annu. Rev. Phytopathol. 52:517-49.

Bouwmeester, H., Heuvelink, G. B. M., and Stoorvogel, J. J. 2016. Mapping crop diseases using survey data: The case of bacterial wilt in bananas in the East African highlands. Eur. J. Agron. 74.

Brandt, S. A., Spring, A., Hiebsch, C., McCabe, J. T., Tabogie, E., Wolde-Michael, G., et al. 1997. The "Tree Against Hunger": Enset-based Agricultural System in Ethiopia. Adv. Sci. :56.

Bruce, T. J. A. 2010. Tackling the threat to food security caused by crop pests in the new millennium. Food Secur. 2:133-141.

Camacho, C., Coulouris, G., Avagyan, V., Ma, N., Papadopoulos, J., Bealer, K., et al. 2009. BLAST+: Architecture and applications. BMC Bioinformatics. 10:1-9.

Carter, B. A., Reeder, R., Mgenzi, S. R., Kinyua, Z. M., Mbaka, J. N., Doyle, K., et al. 2010. Identification of Xanthomonas vasicola (formerly $X$. campestris pv . musacearum), causative organism of banana xanthomonas wilt, in Tanzania, Kenya and Burundi. Plant Pathol. 59:403.

Castellani, E. 1939. Su un marciume dell' ensete. L'Agric. Colon. Firenze. 33:297-300.

Center for International Earth Science Information Network, C. C. U. 2017. Gridded Population of the World, Version 4 (GPWv4): Population Count, Revision 10. Available at: https://doi.org/10.7927/H4PG1PPM.

Challis, R., Richards, E., Rajan, J., Cochrane, G., and Blaxter, M. 2020. BlobToolKit - Interactive Quality Assessment of Genome Assemblies. G3 Genes, Genomes, Genet. 10:g3.400908.2019.

Doyle, J., Doyle, J. L. 1987. Genomic plant DNA preparation from fresh tissue-CTAB method. Phytochem Bull. 19:11-15.

Fick, S. E., and Hijmans, R. J. 2017. WorldClim 2: new 1-km spatial resolution climate surfaces for global land areas. Int. J. Climatol. 37:4302-4315.

Forum, P. O., Carvajal-Yepes, M., Cardwell, K., Nelson, A., Garrett, K. A., Giovani, B., et al. 2019. A global surveillance system for crop diseases. Science (80-. ). 364:1237-1239 Available at: http://science.sciencemag.org/content/364/6447/1237.abstract.

Fu, L., Niu, B., Zhu, Z., Wu, S., and Li, W. 2012. CD-HIT: Accelerated for clustering the next- 
generation sequencing data. Bioinformatics. 28:3150-3152.

Goss, E. M., and Bergelson, J. 2006. Variation in resistance and virulence in the interaction between Arabidopsis thaliana and a bacterial pathogen. Evolution (N. Y). 60:1562-1573.

Haile, B., Fininsa, C., Terefe, H., Chala, A., and Hussen, S. 2020. Evaluation of enset (Ensete ventricosum) clones for resistance reaction against pathogenic Xanthomonas campestris pv. musacearum isolates from Southwestern Ethiopia. Cogent Food Agric. 6 Available at: https://doi.org/10.1080/23311932.2020.1773094.

Heeb, L., Jenner, E., and Cock, M. J. W. 2019. Climate - smart pest management : building resilience of farms and landscapes to changing pest threats. J. Pest Sci. (2004). 92:951-969 Available at: https://doi.org/10.1007/s10340-019-01083-y.

Hijmans, R. J. 2017. raster: Geographic Data Analysis and Modeling. R package version 2.6-7.

Hijmans, R. J., Philips, S., Leathwick, J., and Elith, J. 2017. dismo: Species Distribution Modeling. R package version 1.1-4.

Hunduma, T., Kassahun, S., Hilu, E., and Oli, M. 2015. Evaluation of Enset Clones Resistance against Enset Bacterial Wilt Disease (Xanthomonas campestris pv. musacearum). J. Vet. Sci. Technol. 06 Available at: http://www.omicsonline.org/open-access/evaluation-of-enset-clonesresistance-against-enset-bacterial-wilt-disease-xanthomonas-campestris-pv-musacearum-21577579-1000232. php?aid=52024.

Jarvis, A., Reuter, H. I., Nelson, A., and Guevara, E. 2008. Hole-filled SRTM for the globe Version 4, available from the CGIAR-CSI SRTM 90m Database. Available at: http://srtm.csi.cgiar.org.

Jones, D. R. 2000. Diseases of Banana, Abacá and Enset. Walingford, Reino Unido: CABI Publishing.

Jones, D. R. 2018. Handbook of diseases of banana, abaca and enset. CABI.

Kriticos, D. J., Webber, B. L., Leriche, A., Ota, N., Macadam, I., Bathols, J., et al. 2012. CliMond: Global high-resolution historical and future scenario climate surfaces for bioclimatic modelling. Methods Ecol. Evol. 3:53-64.

Lemawork, S., Azerefegne, F., Alemu, T., Addis, T., and Blomme, G. 2018. Hot water immersion disinfests enset ( Ensete ventricosum ) suckers from the enset root mealybug Cataenococcus ensete Williams and Matile-Ferrero. 13:1990-1997.

Lescot, T. 1988. Influence of altitude on populations of banana weevil (Cosmopolites sordidus Germar). Fruits (France). 43:433-437.

Lever, J., Krzywinski, M., and Altman, N. 2017. Principal component analysis. Nat. Publ. Gr. 14:641-642 Available at: http://dx.doi.org/10.1038/nmeth.4346.

McKnight-CCRP. 2013. "Integrated Management of Bacterial Wilt of Enset (Ensete ventricosum (Welw.) Cheesman) caused by Xanthomonas campestris pv. musacearum in Ethiopia.

Merga, I., Tripathi, L., Hvoslef-Eide, A., and Gebre, E. 2019. Application of Genetic Engineering for Control of Bacterial Wilt Disease of Enset, Ethiopia's Sustainability Crop. Front. Plant Sci. 10.

Muzemil, S., Chala, A., Tesfaye, B., Studholm, D. J., Grant, M., Yemataw, Z., et al. 2020. Evaluation of 20 enset (Ensete ventricosum) landraces for response to Xanthomonas vasicola 
636

637

638

639

640

641

642

643

644

645

646

647

648

649

650

651

652

653

654

655

656

657

658

659

660

661

662

663

664

665

666

667

668

669

670

671

672

673

674

675

676 pv. musacearum infection. bioRxiv.

Naimi, B. 2017. Package ' usdm .'

Nakato, G. V., Beed, F., Bouwmeester, H., Ramathani, I., Mpiira, S., Kubiriba, J., et al. 2016.

Building agricultural networks of farmers and scientists via mobile phones: case study of banana disease surveillance in Uganda. Can. J. Plant Pathol. 38:307-316 Available at: https://doi.org/10.1080/07060661.2016.1230149.

Neil, R., Miller, G., Sergio, G., Alves, C., and Sluys, M. Van. 2017. Plant immunity: unravelling the complexity of plant responses to biotic stresses. :681-687.

O'Leary, N. A., Wright, M. W., Brister, J. R., Ciufo, S., Haddad, D., McVeigh, R., et al. 2016. Reference sequence (RefSeq) database at NCBI: Current status, taxonomic expansion, and functional annotation. Nucleic Acids Res. 44:D733-D745.

Ocimati, W. D., Bouwmeester, H., Groot, J. C. J., Tittonell, P., Brown, D., and Blomme, G. 2019. The risk posed by Xanthomonas wilt disease of banana: Mapping of disease hotspots, fronts and vulnerable landscapes. PLoS One. 14:1-19.

Ocimati, W., Ssekiwoko, F., Karamura, E., Tinzaara, W., and Eden-green, S. 2013. Systemicity of Xanthomonas campestris pv . musacearum and time to disease expression after inflorescence infection in East African highland and Pisang Awak bananas in Uganda. Plant Pathol. 62:777-785.

OpenStreetMap contributors. 2015. OSM. Planet dump \$DATE.

Ott, A., Liu, S., Schnable, J. C., Yeh, C. T., Wang, K. S., and Schnable, P. S. 2017.

tGBSßgenotyping-by-sequencing enables reliable genotyping of heterozygous loci. Nucleic Acids Res. 45.

Pateiro-lopez, M. B. 2019. Package ' alphahull .'

Pironon, S., Etherington, T. R., Borrell, J. S., Kuhn, N., Macias-Fauria, M., Ondo, I., et al. 2019. Potential adaptive strategies for 29 Sub-Saharan crops under future climate change. Nat. Clim. Chang. 9:758-763.

Quimio, A. J. 1992. Annual report of the plant pathologist: July 17, 1991- July 16, 1992. Enset Team Support Project. Sidamo Gamo-Goffa Peasant agricultural Development Program.

Quimio, A. J. 1991. First quarter report of the plant pathologists: July 1- September 30, 1991. Enset Team Support Project. Sidamo Gamo Goffa Peasant agricultural Development Program. PADEP III.

Quimio, A. J., Mesfin, T., and Tessera, M. 1996. Diseases of Enset. In In: Tsedeke A., Hiebsch, C., Brandt, S.A., Seifu G.M. (Eds.), pp. 188-203. Enset-Based Sustainable Agriculture in Ethiopia. Proceedings of the International Work shop on enset. Addis Ababa, Ethiopia, 13-20 December 1993., eds. A. Tsedeke, H. Clifton, S.A. Brandt, and G. Seifu. Addis Ababa, Ethiopia, p. 188-203.

R Core team. 2019. R: A language and environment for statistical computing. Vienna, Austria: $\mathrm{R}$ Foundation for Statistical Computing.

Sahle, M., Yeshitela, K., and Saito, O. 2018. Mapping the supply and demand of Enset crop to improve food security in Southern Ethiopia. Agron. Sustain. Dev. 38:7 Available at:

http://link.springer.com/10.1007/s13593-017-0484-0. 
677

678

679

680

681

682

683

684

685

686

687

688

689

690

691

692

693

694

695

696

697

698

699

700

701

702

703

704

705

706

707

708

709

710

711

712

713

714

715

716

717

Salter, S. J., Cox, M. J., Turek, E. M., Calus, S. T., Cookson, W. O., Moffatt, M. F., et al. 2014. Reagent and laboratory contamination can critically impact sequence-based microbiome analyses. :1-12.

Savary, S., Ficke, A., Aubertot, J., and Hollier, C. 2012. Crop losses due to diseases and their implications for global food production losses and food security. Food Secur. :519-537.

Savary, S., Willocquet, L., Pethybridge, S. J., Esker, P., Mcroberts, N., and Nelson, A. 2019.

The global burden of pathogens and pests on major food crops. Nat. Ecol. Evol. 3:430-439 Available at: http://dx.doi.org/10.1038/s41559-018-0793-y.

Shank, R., and Ertiro, C. 1996. A Linear Model for Predicting Enset Plant Yield and Assessment of Kocho Production in Ethiopia. Addis Ababa.

Shimelash, D., Alemu, T., Addis, T., Turyagyenda, F. L., and Blomme, G. 2008. Banana Xanthomonas Wilt in Ethiopia: Occurrence and Insect Vector Transmission. African Crop Sci. J. 16:75-87.

Shimwela, M. M., Ploetz, R. C., Beed, F. D., Jones, J. B., Blackburn, J. K., Mkulila, S. I., et al. 2016. Banana xanthomonas wilt continues to spread in Tanzania despite an intensive symptomatic plant removal campaign: an impending socio-economic and ecological disaster. Food Secur. 8:939-951 Available at: http://dx.doi.org/10.1007/s12571-016-0609-3.

Spring, A. 1996. Enset farming systems in southern region, ethiopia: Report on a rapid rural appraisal in Gurage, Hadiya, and Sidama Zones.

Studholme, D. J., Wicker, E., Abrare, S. M., Aspin, A., Bogdanove, A., Broders, K., et al. 2019. Transfer of Xanthomonas campestris $\mathrm{pv}$. arecae and $X$. campestris $\mathrm{pv}$. musacearum to $X$. vasicola ( Vauterin ) as X . vasicola pv . arecae. Phytopathology. :1-8.

Tadesse, M., Babosha, K., Diro, M., and Wolde-Michael, G. 2003. Enset bacterial wilt sanitary control in Gurage Zone. :23.

Tamrat, S., Borrell, J. S., Biswas, M. K., Gashu, D., Wondimu, T., and Carlos, A. 2020. Micronutrient composition and microbial community analysis across diverse landraces of the Ethiopian orphan crop enset. BioRxiv.

Tessera, M., and Quimio, A. J. J. 1994. Research on enset pathology. In Proceedings of the 2nd National Horticultural Workshop of Ethiopia, eds. E Herath and L Desalegn. Institute of Agricultural Research, Addis Ababa.: IAR, p. 217-225.

Tewodros, M., and Tesfaye, W. 2014. Farmers indigenous knowledge and assessment of enset (Ensete ventricosum Welw . Cheesman) cultivars for major insect pests in Ojojia water shade Kembata- tembaro zone, South Ethiopia. Sky J. Agric. Res. 3:112-119.

Title, P. O., and Bemmels, J. B. 2018. ENVIREM: an expanded set of bioclimatic and topographic variables increases flexibility and improves performance of ecological niche modeling. Ecography (Cop.). 41:291-307.

Tushemereirwe, W. K., Okaasai, O. O., Kubiriba, J., Nankinga, C., Muhangi, J., Odoi, N., et al. 2006. Status of banana bacterial wilt in Uganda. African Crop Sci. J. 14:73-82.

Uwamahoro, F., Berlin, A., Bylund, H., Bucagu, C., and Yuen, J. 2019. Management strategies for banana Xanthomonas wilt in Rwanda include mixing indigenous and improved cultivars.

Agron. Sustain. Dev. 39. 
Vurro, M., Bonciani, B., and Vannacci, G. 2010. Emerging infectious diseases of crop plants in developing countries: impact on agriculture and socio-economic consequences. Food Secur. 2:113-132 Available at: https://doi.org/10.1007/s12571-010-0062-7.

Wasukira, A., Tayebwa, J., Thwaites, R., Paszkiewicz, K., Aritua, V., Kubiriba, J., et al. 2012. Genome-Wide Sequencing Reveals Two Major Sub-Lineages in the Genetically Monomorphic Pathogen Xanthomonas Campestris Pathovar Musacearum. Genes (Basel). 3:361-377.

Welde-Michael, G., Bobosha, K., Addis, T., Blomme, G., Mekonnen, S., and Mengesha, T. 2008. Mechanical transmission and survival of bacterial wilt on enset. African Crop Sci. J. 16:97-102.

Welde-Michael, G., Bobosha, K., Blomme, G., Addis, T., Mengesha, T., Mekonnen, S., et al. 2008. Evaluation of enset clones against enset bacterial wilt. African Crop Sci. J. 16:89-95.

Wolde, M., Ayalew, A., and Chala, A. 2016. Assessment of bacterial wilt (Xanthomonas campestris pv . musacearum) of enset in Southern Ethiopia. African J. Agric. Res. 11:17241733.

Yemataw, Z., Mekonen, A., Chala, A., Tesfaye, K., Mekonen, K., Studholme, D. J., et al. 2017. Farmers' knowledge and perception of enset Xanthomonas wilt in southern Ethiopia. Agric. Food Secur. 6:1-12 Available at: https://doi.org/10.1186/s40066-017-0146-0.

Yemataw, Z., Tesfaye, K., Zeberga, A., and Blomme, G. 2016. Exploiting indigenous knowledge of subsistence farmers' for the management and conservation of Enset (Ensete ventricosum (Welw.) Cheesman) (musaceae family) diversity on-farm. J. Ethnobiol. Ethnomed. 12:34 Available at: http://ethnobiomed.biomedcentral.com/articles/10.1186/s13002-016-0109-8.

Yirgou, D., and Bradbury, J. F. 1968. Bacterial wilt of enset (Ensete ventricosum) incited by Xanthomonas musacearum sp. n. Phytopathology. 58:111-112.

Yirgu, T. 2016. Land use Dynamics and challenges of Enset ( Ensete ventricosum ) agriculture in the upper reaches of Baso-Deme watershed, Gamo Highland, SW Ethiopia. Glob. J. Interdiscip. Soc. Sci. 5:20-28.

Zerfu, A., Gebre, S. L., Berecha, G., and Getahun, K. 2018. Assessment of spatial distribution of enset plant diversity and enset bacteria wilt using geostatistical techniques in Yem special district, Southern Ethiopia. Environ. Syst. Res. 7:23 Available at: https://environmentalsystemsresearch.springeropen.com/articles/10.1186/s40068-018-0126-9. 


\section{Tables}

758 Table 1. Reported pests and pathogens of domesticated enset (Ensete ventricosum) in

759 Ethiopia.

\begin{tabular}{|c|c|c|c|c|}
\hline Disease & Known causal organism & Severity and impact & $\begin{array}{l}\text { Management } \\
\text { advice available }\end{array}$ & References \\
\hline $\begin{array}{l}\text { Enset Bacterial Wilt } \\
\text { (EXW) }\end{array}$ & $\begin{array}{l}\text { Xanthomonas } \\
\text { vasicolapv. musacearum } \\
\text { (Xvm) }\end{array}$ & $\begin{array}{l}\text { Considered the most } \\
\text { important disease of } \\
\text { enset. Potential for } \\
\text { complete crop loss. }\end{array}$ & $\begin{array}{l}\text { Sanitary } \\
\text { Measures }\end{array}$ & $\begin{array}{l}\text { Yirgou and } \\
\text { Bradbury (1968) }\end{array}$ \\
\hline Bacterial corm rot & $\begin{array}{l}\text { Unidentified bacterium, } \\
\text { potentially Erwinia or } \\
\text { Dickeya species }\end{array}$ & $\begin{array}{l}\text { Not known. Potential } \\
\text { for loss of individual } \\
\text { whole plants }\end{array}$ & Not available & $\begin{array}{l}\text { Quimio et al. } \\
\text { (1996) }\end{array}$ \\
\hline Sheath rot of enset & Unidentified & $\begin{array}{l}\text { Not known. Potential } \\
\text { for loss of individual } \\
\text { whole plants. }\end{array}$ & Not available & Quimio (1991) \\
\hline Leaf spot & $\begin{array}{l}\text { Phyllostica sp., } \\
\text { Pyiricularia sp., and } \\
\text { Drechslera sp }\end{array}$ & Not known & Not available & $\begin{array}{l}\text { Quimio et al. } \\
(1996)\end{array}$ \\
\hline Leaf spot & $\begin{array}{l}\text { Cladosporium Sp. and } \\
\text { Deightoniella Sp. }\end{array}$ & Not known & Not available & $\begin{array}{l}\text { Quimio et al. } \\
\text { (1996) }\end{array}$ \\
\hline Sigatoka & $\begin{array}{l}\text { Mycosphaerella } \\
\text { musicola }\end{array}$ & Not known & $\begin{array}{l}\text { Not available, but } \\
\text { potentially } \\
\text { available from } \\
\text { Banana. }\end{array}$ & $\begin{array}{l}\text { Quimio et al. } \\
(1996)\end{array}$ \\
\hline $\begin{array}{l}\text { Sclerotium wilt and } \\
\text { root rot }\end{array}$ & Sclerotium rolfsi & Not known & Not available & (Quimio 1992) \\
\hline $\begin{array}{l}\text { Mosaic and } \\
\text { chlorotic streak }\end{array}$ & Unidentified & Not known & Not available & $\begin{array}{l}\text { (Quimio 1992, } \\
\text { 1991) }\end{array}$ \\
\hline $\begin{array}{l}\text { Root knot } \\
\text { nematode }\end{array}$ & Meloidogyne sp. & Not known & Not available & $\begin{array}{l}\text { (Tessera and } \\
\text { Quimio 1994) }\end{array}$ \\
\hline Vertebrate pests & $\begin{array}{l}\text { Porcupine, mole rat, } \\
\text { pigs, monkeys) }\end{array}$ & $\begin{array}{l}\text { Not known. Potential } \\
\text { disease vector. }\end{array}$ & $\begin{array}{l}\text { Cultural practices, } \\
\text { traps }\end{array}$ & $\begin{array}{l}\text { Kefale and } \\
\text { Stephen, (1991) }\end{array}$ \\
\hline Leaf hopper & Sophonia sp & $\begin{array}{l}\text { Not known. Potential } \\
\text { disease vector. }\end{array}$ & Not available & (Zerfu et al. 2018) \\
\hline $\begin{array}{l}\text { Enset root } \\
\text { mealybug }\end{array}$ & Cataenococcus ensete & $\begin{array}{l}\text { Likely to be localised } \\
\text { yield reductions due } \\
\text { to retardation of } \\
\text { growth. Potential } \\
\text { disease vector }\end{array}$ & $\begin{array}{l}\text { Integration of } \\
\text { methods (boiling } \\
\text { water treatments, } \\
\text { cultural practices, } \\
\text { botanicals, use of } \\
\text { insecticide) }\end{array}$ & $\begin{array}{l}\text { Lemawork et al. } \\
\text { (2018); Addis, } \\
\text { Azerefegne, } \\
\text { Blomme, et al. } \\
\text { (2008) }\end{array}$ \\
\hline
\end{tabular}

*We note that whilst in many cases 'Management advice' is not available or reported, there may nevertheless be local cultural practices that warrant further research and investigation 
760 Table 2. Comparison of farmer perceived constraints and associated proportion of

761 farms on which each pest or pathogen was recorded. Columns one and two denote the

762 reported constraint; subsequent columns show the proportion of those farms in which

763 each pest or pathogen was recorded.

\begin{tabular}{lllllll}
\hline $\begin{array}{l}\text { Farmer reported } \\
\text { constraint }\end{array}$ & Number of & \multicolumn{5}{c}{ Proportion of farms in which species was recorded } \\
reports* & EXW & Root mealybug & Corm rot & Molerat & Porcupine \\
\hline RXW & $265(45.9 \%)$ & 0.71 & 0.29 & 0.48 & 0.31 & 0.42 \\
Coot mealybug & $48(8.3 \%)$ & 0.15 & 0.98 & 0.31 & 0.13 & 0.38 \\
Molerat & $87(15.1 \%)$ & 0.07 & 0.21 & 1.00 & 0.13 & 0.28 \\
Porcupine & $49(8.5 \%)$ & 0.20 & 0.45 & 0.39 & 0.98 & 0.47 \\
\hline
\end{tabular}

* Three additional respondents reported Wild pigs, one leaf blight and one leaf hopper. 
780 Table 3. Kendall rank correlation coefficient for each spatial variable and the PCA-

781 derived distribution of each pest and pathogen.

\begin{tabular}{llllll}
\hline Spatial variables & EXW & $\begin{array}{l}\text { Corm } \\
\text { rot }\end{array}$ & $\begin{array}{l}\text { Root } \\
\text { mealybug }\end{array}$ & Molerat & Porcupine \\
\hline Thornthwaite aridity index & 0.038 & -0.039 & -0.010 & -0.090 & 0.007 \\
Precipitation of wettest week & 0.014 & 0.020 & -0.055 & 0.022 & -0.091 \\
Precipitation of warmest quarter & -0.008 & 0.027 & -0.088 & 0.097 & -0.026 \\
Precipitation of coldest quarter & 0.016 & 0.030 & -0.129 & 0.035 & -0.078 \\
Mean diurnal temperature range & 0.030 & -0.022 & 0.008 & -0.091 & 0.050 \\
Isothermality & -0.037 & 0.042 & -0.122 & 0.039 & -0.036 \\
Climatic Moisture Index & 0.001 & 0.044 & -0.076 & 0.090 & -0.102 \\
continentality & 0.050 & -0.055 & 0.060 & -0.104 & 0.017 \\
Max Temp. Coldest & -0.047 & -0.053 & 0.048 & -0.054 & 0.044 \\
PET Coldest Quarter & -0.050 & -0.046 & 0.118 & -0.008 & 0.060 \\
PET Driest Quarter & -0.010 & -0.044 & 0.124 & -0.075 & 0.054 \\
PET Wettest Quarter & 0.030 & -0.080 & 0.068 & -0.105 & 0.021 \\
Topographic position Index & 0.004 & -0.009 & -0.009 & -0.014 & 0.012 \\
Elevation & 0.032 & 0.039 & -0.030 & 0.048 & -0.029 \\
Distance to a major road & 0.001 & 0.045 & 0.008 & 0.038 & -0.047 \\
\hline
\end{tabular}

782

783

784

785

786

787

788

789

790

791 
793 Table 4. Pairwise niche overlap across the five major enset pests and pathogens.

794 Lower triangle indicates overlap at 10\% prevalence quantile. Upper triangle indicates

795 overlap at $90 \%$ prevalence quantile.

\begin{tabular}{llllll}
\hline $\begin{array}{l}\text { Pests and } \\
\text { pathogens }\end{array}$ & EXW & Corm rot & Root mealybug & Molerat & Porcupine \\
\hline EXW & - & 0.32 & 0.01 & 0.05 & 0.33 \\
Corm rot & 0.96 & - & 0.02 & 0.04 & 0.24 \\
Root mealybug & 0.91 & 0.91 & - & 0.00 & 0.20 \\
Molerat & 0.84 & 0.85 & 0.91 & - & 0.03 \\
Porcupine & 0.96 & 0.96 & 0.94 & 0.87 & - \\
\hline
\end{tabular}

796

797

798

799

800

801

802

803

804

805

806

807

808

809

810

811

812

813

814

815 
bioRxiv preprint doi: https://doi.org/101101/2020.06.18.144261; this version posted June 18,2020 . The copyright holder for this preprint (which was not certified by peer review) is the author/funder, who has granted bioRxiv a license to display the preprint in perpetuity. It is made available under aCC-BY-NC 4.0 International license.
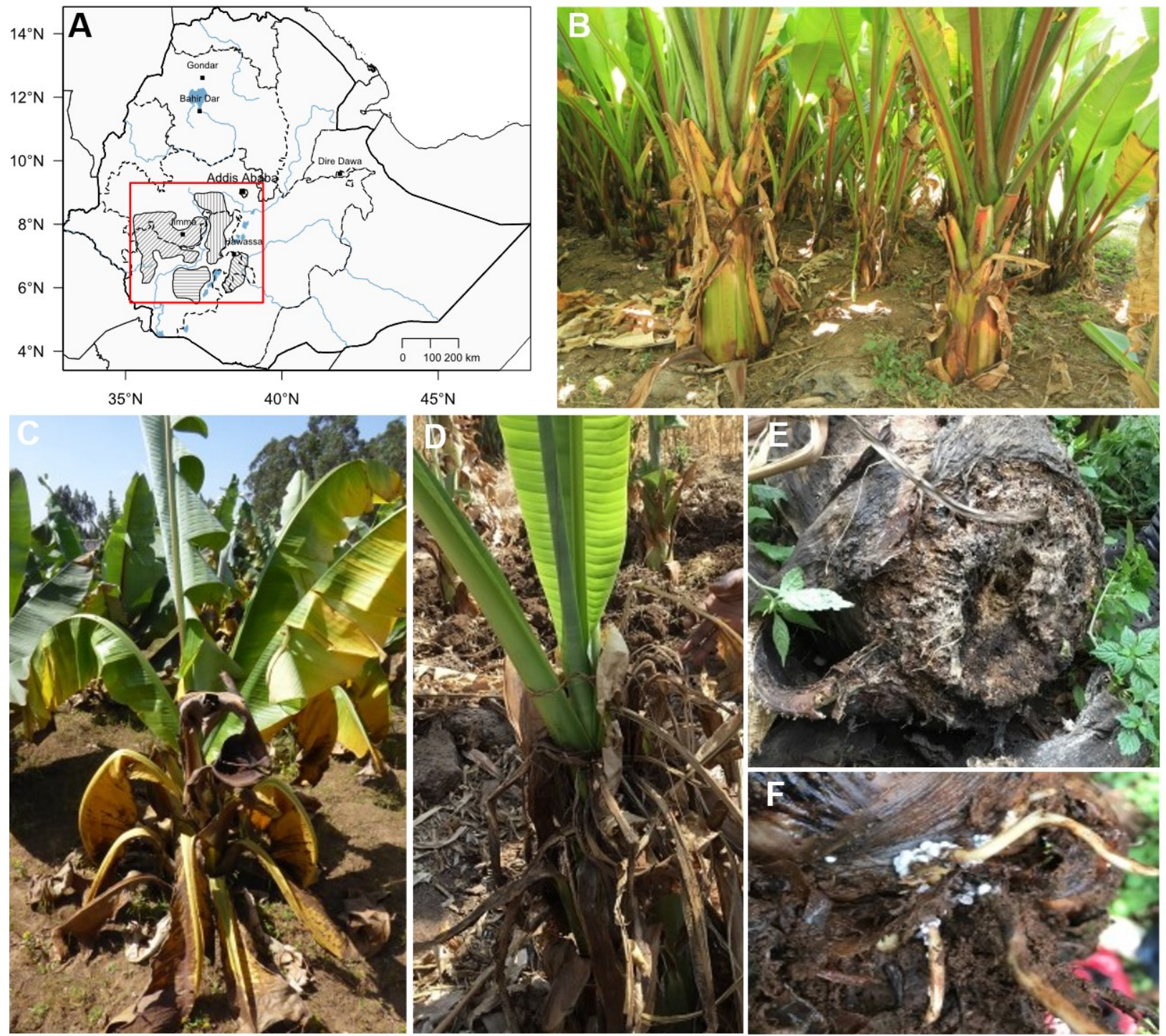

817 Figure 1. Study area and major enset pests and pathogens in Ethiopia. A) Map of

818 Ethiopia, with shaded polygons denoting main regions of enset agriculture and red

819 boundary indicating the extent of our study area. B) Typical enset plot. C) Enset with

821 apparently recovering from severe EXW. E) Enset with evidence of corm rot. F) Root

822 mealybugs on enset corm and roots. 

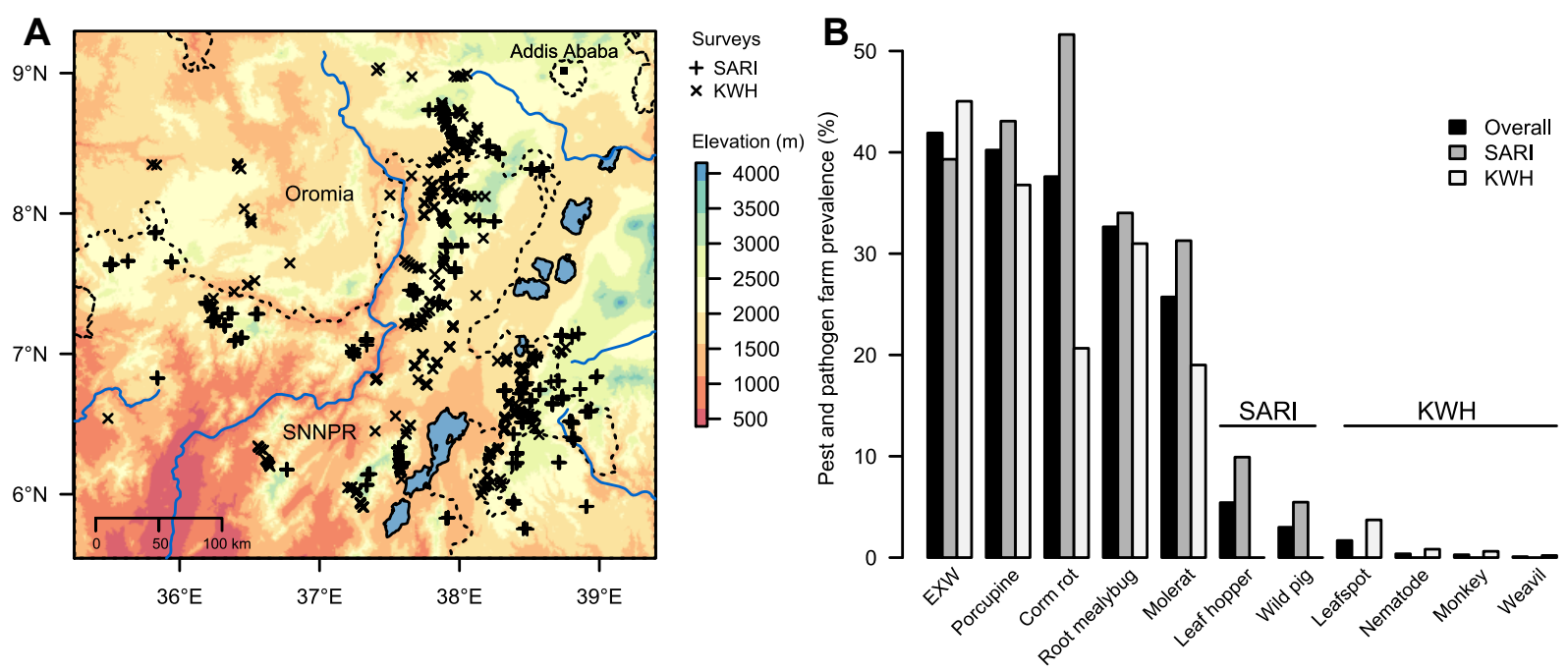

823

824

825

826

827

828

829

830

831

832

833

834

835

836

837

838

839

840

841

Figure 2. Summary of enset pest and pathogen surveys. A) Spatial distribution of

the two independent enset pest and pathogen surveys analysed in this study. B)

Percentage of farm surveys that recorded each of 11 enset pests and pathogens. 

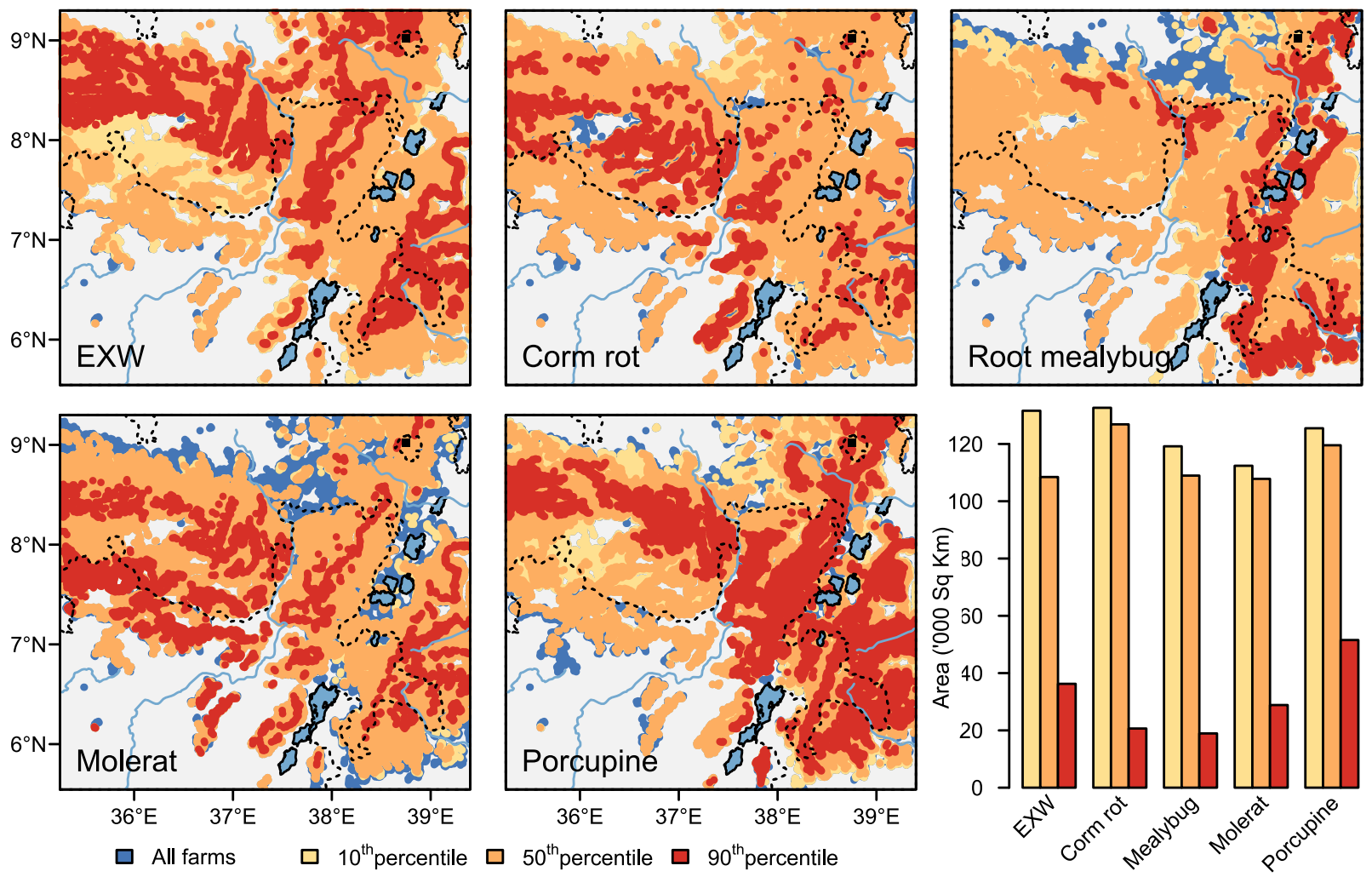

842

843

Figure 3. Distribution maps of five major enset pests and pathogens. Colour scales 

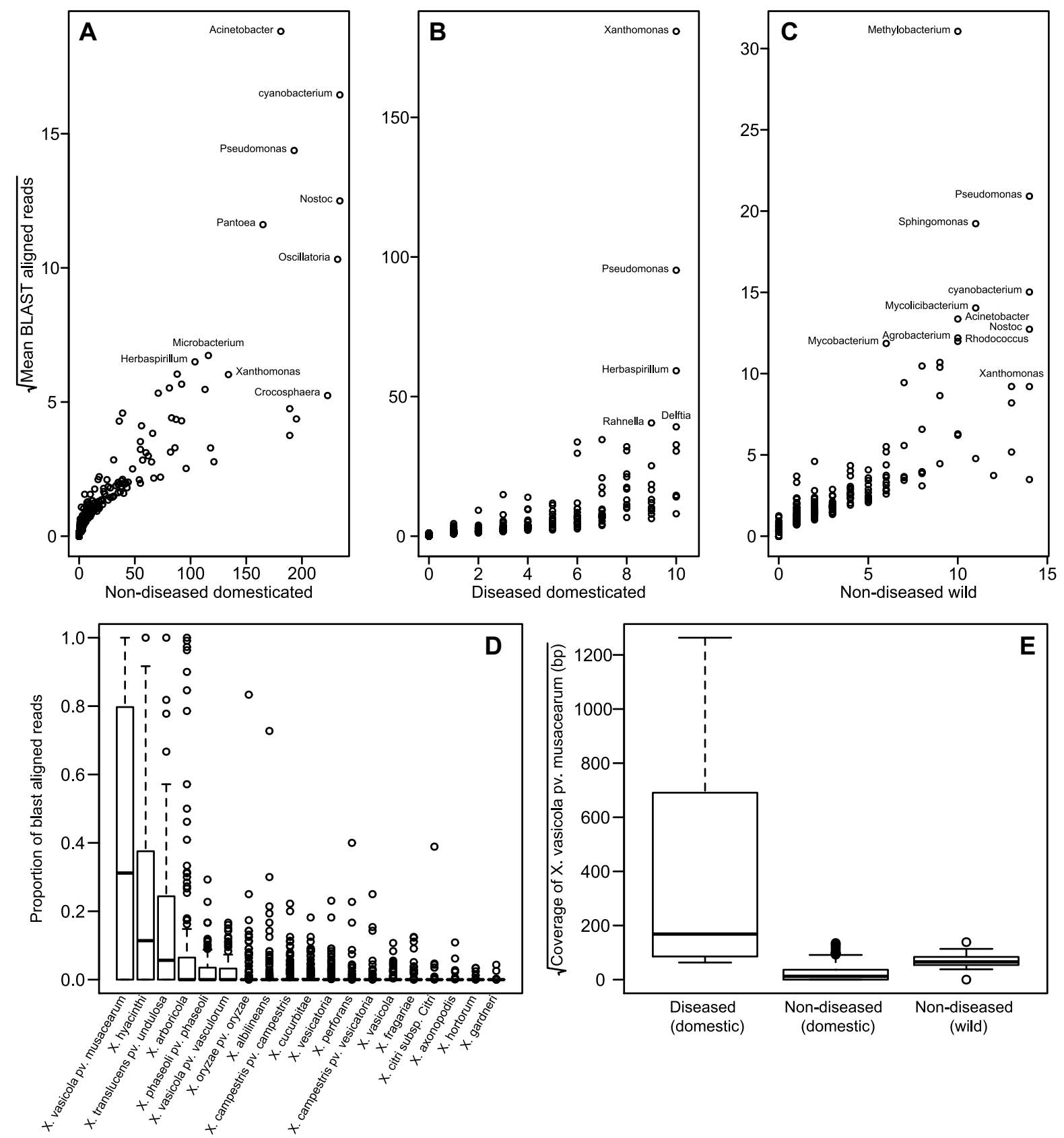

Figure 4. Enset leaf microbiome characterisation based on blast aligned raw

genotyping-by-sequencing reads. A-C) Microbial genera identified in diseased and

non-diseased enset samples. D) Number of reads aligning to each of 19 Xanthomonas

reference sequences. E) Total coverage of Xanthomonas vasicola pv. musacearum

blast aligned reads for each enset sample, grouped by disease status and 


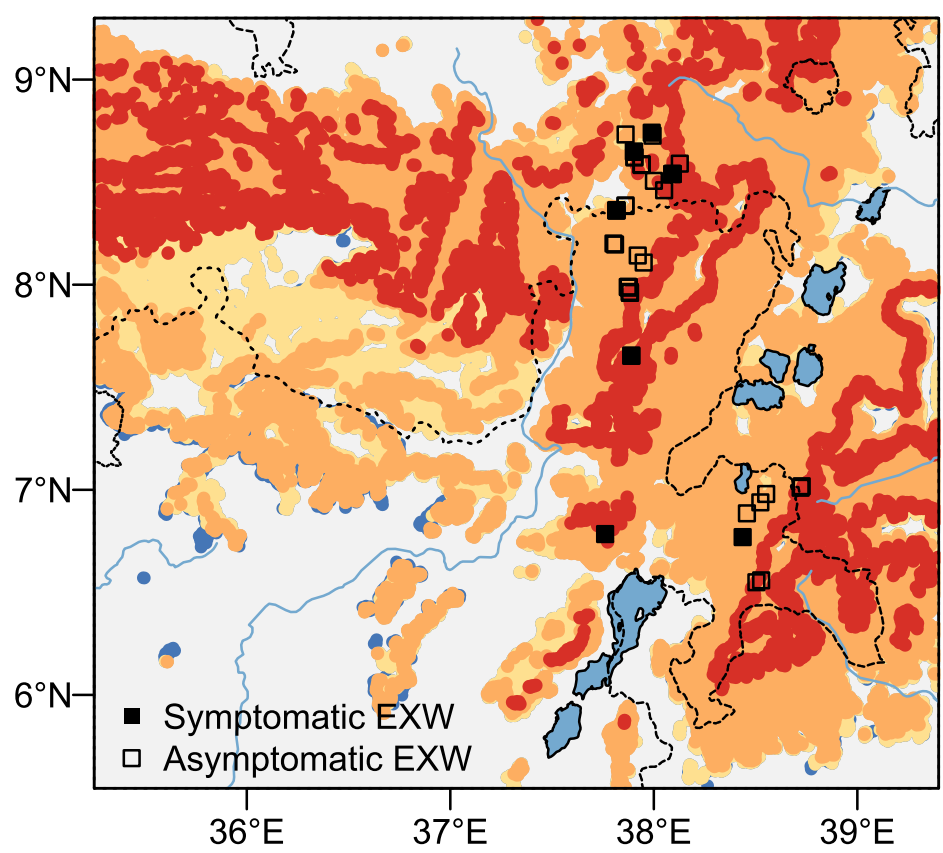

Figure 5. Distribution of EXW symptomatic and asymptomatic enset samples in south west Ethiopia. Background map is modelled enset distribution (Figure 3). The

867 minimum $X v m$ read count in symptomatic samples was 4000 . Here, we plot the 37 asymptomatic individuals with an equal or greater number of $X v m$ reads. 